\title{
A review of virtual reality videogames for job-training applications
}

\section{Una revisión de videojuegos de realidad virtual para aplicaciones de entrenamiento laboral}

\author{
Cristian Adarve-Gómez a, Dily Alexandra Castillo-Carvajal b, Erika Juliett Restrepo-Zapata c \\ \& Hernán Francisco Villar-Vega d \\ a Centro de Servicios y Gestión Empresarial - CESGE, Servicio Nacional de Aprendizaje SENA, Medellín-Colombia, \\ arlex50@gmail.com \\ ${ }^{b}$ Gestor de Proyectos, Red Tecnoparque SENA Nodo Medellín - Grupo GIGAT, Servicio Nacional de Aprendizaje SENA, \\ Medellín-Colombia, dilycastilloc@misena.edu.co \\ c Centro de Servicios y Gestión Empresarial - CESGE, Grupo GIGAT, Servicio Nacional de Aprendizaje SENA, Medellín- \\ Colombia, ejrestrepo28@misena.edu.co

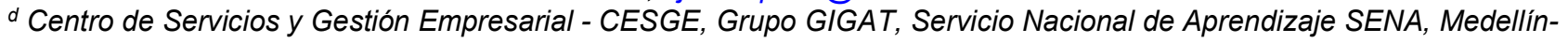 \\ Colombia, hvillar@misena.edu.co
}

Recibido: octubre 12, 2019. Aceptado: diciembre 13, 2019.

\begin{abstract}
Information and Communication Technologies (ICT) are considered as crucial elements in educational processes, as they constitute relevant and necessary tools in the search for higher levels of socioeconomic development. In this context, ICTs have raised the challenge of finding pedagogical models that maximize their impact on teachers and students. The Business Services and Management Center of the SENA Regional Antioquia has a wide range of technical training programs, for a rapid immersion into the labor market, which implies the use of training technologies to ease the understanding of theoretical concepts and the practice of technical procedures. In addition, these programs require the development of skills allowing their students to perform correctly in the workplace. Considering the above, videogames arise as an alternative tool for training operations. This article presents a review of training tools based on virtual reality, focusing mainly on the design of the game elements and their dynamics, which can contribute to magnify user experiences. Moreover, we present some projects showing success stories in the learning process and discussing the impact of the elements and game mechanics.
\end{abstract}

Keywords: Virtual reality, Job training, Serious games, Videogames.

\section{Resumen}

Las Tecnologías de la Información y la Comunicación (TIC) se consideran elementos cruciales en los procesos educativos, ya que constituyen herramientas relevantes y necesarias en la búsqueda de niveles más altos de desarrollo socioeconómico. En este contexto, las TIC han planteado el desafío de encontrar modelos pedagógicos que maximicen su impacto en profesores y estudiantes. El Centro de Servicios y Gestión Empresarial del SENA Regional Antioquia cuenta con una amplia gama de programas de capacitación características técnica, destinados a una rápida inmersión en el mercado laboral, lo que implica el uso de tecnologías de capacitación para facilitar la comprensión de conceptos teóricos y la práctica de procedimientos técnicos. Además, estos programas requieren el desarrollo de habilidades que permitan a sus estudiantes desempeñarse correctamente en el lugar de trabajo. Al considerar lo expuesto, los videojuegos surgen como una herramienta alternativa para las operaciones de entrenamiento. Este artículo presenta una revisión de las herramientas de entrenamiento basadas en la realidad virtual, centrándose en el diseño de los elementos del juego y sus dinámicas, que pueden contribuir a magnificar las experiencias del usuario. Además, presentamos algunos proyectos que muestran historias de éxito en el proceso de aprendizaje y discuten el impacto de los elementos y la mecánica del juego.

Palabras Clave: Realidad virtual, Entrenamiento laboral, Juegos serios, Videojuegos.

\section{INTRODUCCIÓN}

Virtual Reality (VR) is a term denoting a wide composition of interactive computer simulations, including the human-machine interface. VR focuses on the user and allows complete immersion in a computer-generated 3D graphic simulation experience to navigate and interact with the virtual environment in real-time [1]. There are

\section{Citar como:}

C. Adarve, D. Castillo, E. Restrepo, H. Villar-Vega. "A review of virtual reality videogames for jobtraining applications" Revista CINTEX, Vol. 24(1), pp. 64-70. 2019 
numerous definitions of the term "Virtual Reality," almost as many as researchers. Still, we will consider the following: "Virtual Reality is a dynamic three-dimensional simulation in which the user feels introduced in

an artificial environment that perceives as real based on stimuli to the sensory organs" [2]. From the previous definition, the needs or requirements that a Virtual Reality installation must meet can be identified, among which the following stand out:

- Simulation: Ability to represent a system with enough resemblance to the reality, to convince the user that it constitutes a situation parallel to that. This environment will be governed by a series of rules, not necessarily the same as the real world.

- Interaction: Having control of the system created so that the actions of the user produce changes in the artificial world. There are several man-machine interfaces to achieve this interaction, ranging from the simplest as keyboard and mouse to more advanced ones such as gloves or sensory suits.

- Perception: It is the most important factor of all. Currently, the systems of Virtual Reality are primarily directed at the senses (sight, hearing, touch) by external elements (display helmets, data gloves, humanmachine interfaces). However, it is possible that in the future, they will try to reach the brain directly, thus avoiding external sensory interfaces.

On the other hand, education for work is a process where people learn the basic technical elements to perform a job. In this educational category, the goal is to acquire the knowledge and skills necessary to perform their activities properly in the productive sector. One way to achieve this objective is by using so-called serious games, a class of videogames that go beyond entertainment and have a planned educational purpose. These videogames are used in job training so that the training is immersive, and users are put in professional situations promoting a better acquisition of knowledge, practices, and behaviors. For apprentices, these features of serious games allow for a better "experimentation" of life situations in almost real (simulated) environments. Several works have demonstrated that when apprentices face the same situations in a real environment, they act efficiently [3], [4], and improve decision-making without having real consequences [5]. These serious videogames are mainly used for job training in areas such as engineering [6], [7], mathematics [8], medicine [9] and software development [10], among others.

The Business Services and Management Center of the SENA Regional Antioquia [11] has a wide range of training programs of technical characteristics. These programs are intended for a rapid immersion into the labor market, which implies the use of training technologies to ease the understanding of theoretical concepts and the practice of technical procedures [12]. Also, these programs require the development of skills allowing their students to perform correctly in the workplace. In this context, videogames arise as an alternative tool for training operations. This article presents a review of training tools based on virtual reality, which can contribute to magnify user experiences.

\section{METHODOLOGY FOR LITERATURE SEARCH}

This article presents documentary research, where different investigations were analyzed concerning the importance of videogames for job-training applications. The review involved the search and analysis of different tools based on virtual reality, mainly employed to strengthen labor competencies. The main purpose was to recognize the elements and dynamics of the videogame to identify how these features contribute to the user experience.

As proposed in [13], we searched publications with the terms "VR" and "serious games" in databases such as Science Direct, IEEE, and Google Scholar. Only publications from the last five years were considered, resulting in 133 articles. A first analysis of the occurrence of the keywords in the search results, using the VOSviewer software, yielded the classification shown in Figure 1, which presents "VIRTUAL REALITY" as the main term, followed by "TRAINING" and "AUGMENTED REALITY". Also appear terms such as "INDUSTRY 4.0", "SIMULATION", "SUGICAL TRAINING", among others. 


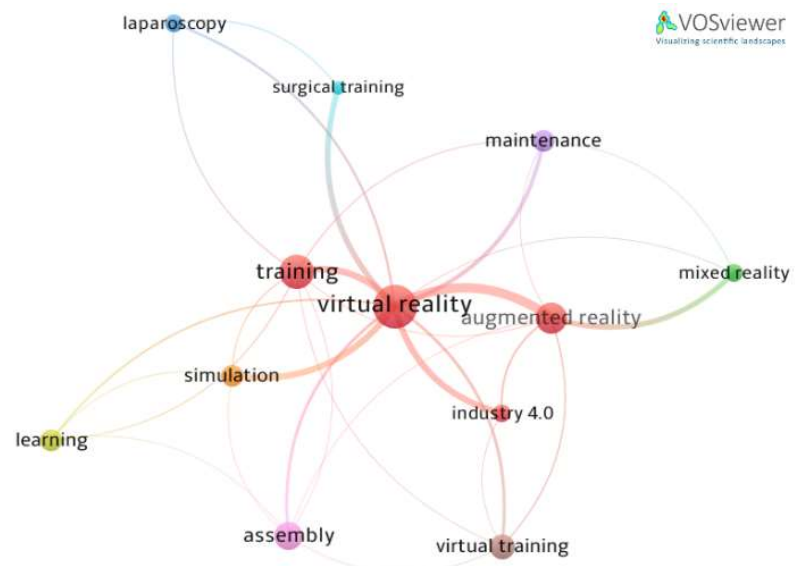

Figure 1. Analysis of primary studies using VOSviewer. (Own elaboration)

The title and summary of the selected articles were analyzed, excluding applications that were not related to job training, such as rehabilitation, social and emotional skills, or developments with augmented reality. Subsequently, we assigned a relevance integer weight from 0 to 5 to each paper, where 5 is the score most relevant information, and 0 denotes the score given to the articles that, despite calling the attention of the researchers, do not present significant contributions for this study. After this weighting process, only the articles rated with scores of 4 and 5 were considered for the preparation of this work. Figure 2 describe the review process.

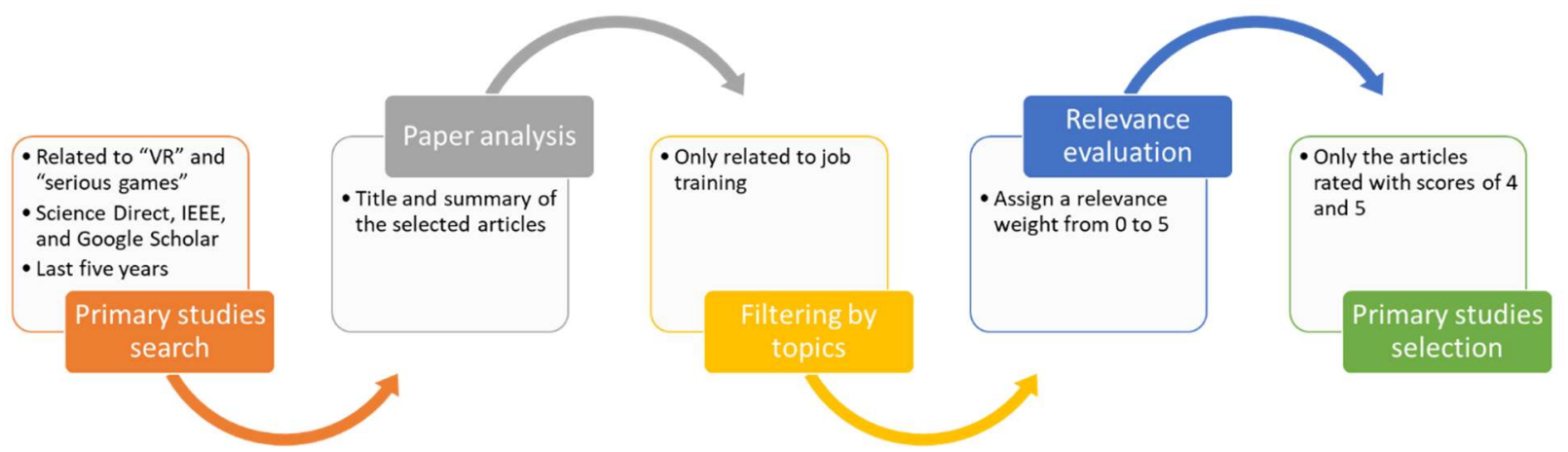

Figure 2. Methodology for literature review. (Own elaboration)

\section{VIRTUAL REALITY-BASED SOLUTIONS}

Internationally, one of the largest deployments of VR-based solutions was registered by STRIVR, one of the leading companies for training application development in the United States. They have worked on developments for companies such as Walmart, Chipotle, and Verizon. For its pilot program with Walmart, approximately 17,000 Oculus Go devices were distributed to locations throughout the country, one of the largest such operations in history. With this deployment, they have trained more than 140,000 employees on issues such as the management of chaos and emergencies caused by massive events like Black Friday. Training participants reported a $30 \%$ higher satisfaction using VR compared to other educational tools. Additionally, $70 \%$ of employees who trained with VR outperformed groups educated with other materials and techniques [14].

Microsoft is one of the largest corporations developing training-focused software and hardware for VR, Augmented Reality (AR) and Mixed Reality (MR). The company recently acquired a contract for 480 million dollars with the US military to provide mixed reality systems (Hololens) for training and operation in combat missions. The contract signed in November of 2018 can lead to the acquisition of more than 100.000 displays, whose objective would be to increase lethality by improving the ability to detect, decide and attack before the enemy. The army asked them to incorporate night and thermal vision, breathing and bruising monitors, and hearing protection [15].

In Peru, immersive VR technology had a role in the training of mining operation employees. The training process related to the identification of hazards, risk assessment, and control measures (IPERC). With the proposed videogame, they managed to improve training efficiency, and its use allowed to increase the level of 
retention and acquisition of knowledge up to $75 \%$ according to the NTL Institute for Applied Behavioral Sciences. A robust rate of $99 \%$ of the staff approved the training and $86 \%$ approved with a score greater than 18 points out of 20, indicating the level of retention achieved with the employed solution [14].

In Colombia, VR solutions are mainly found in the area of health and medical applications. Research shows that different simulators are used to train the user in surgical procedures and to enhance general surgical skills. Referenced works present Virtual Simulators for laparoscopy training such as SIMENDO [16], Laparoscopy [17], BVLaST [18], SYNERGY [19], Simulator of the Central University of Las Villas and the company SimPro [20]. Other kinds of specialized surgical simulators are also emulating specific surgical procedures. Such is the case of Empedocles, whose training modules include Nissen fundoplication, appendectomy and "walking the bowel" exercise [21]. Other tools worth mentioning are the simulator for rectal laparoscopy [22], and the V-Band Simulator [23].

In several SENA Training Centers, researchers have developed serious VR-based games intended for use as job simulators or trainers. Among these, we can mention the Trade Center of the Regional Antioquia, where a laboratory called "Accounting Financial Simulator" was developed in 2015. The lab project gives the apprentices in the accounting area the experience of approaching the business environment [24]. In the same direction, Tecnoparque SENA in Manizales node joined forces with the CHEC Electricity Company to develop VR applications for the power industry. In this joint effort, they executed a project in which an interactive training and immersion process was implemented in VR for underground and aerial power networks. The results led to the development of software to enable training using 3D environments applied to power distribution networks [25].

\section{DISCUSSION}

Simulation of real environments facilitates the development of skills in job-training processes. This is the result of people obtaining experiences that allow them to learn, to make risky decisions and to know their consequences without assuming the costs of making decision mistakes [26], [27]. VR training tools can be used without constant supervision, easing the task of teachers and instructors [28]. However, for achieving the training goal, the environment must be as similar as possible to the reality to produce meaningful learning [29], [30]. In this way, users can understand more practically the functionality of tools or elements used in construction processes [31], assembly lines [32], or surgical procedures [33].

In the articles reviewed, three major application lines of VR serious games were identified: Health, Industry and Safety/Security [34]. The areas of interest, as shown in Figure 3, are Surgery and Care for the Health line, while Manufacturing and Logistics make up the Industry line. In some research topics, recurring themes were found: Mental Health [35] within Care, Processes [36] and Construction [37] within Logistics and Occupational Health [38] and Rescue [39] within Security. Figure 4 shows a taxonomy of the main topics of interest in VR applications for on-the-job training.

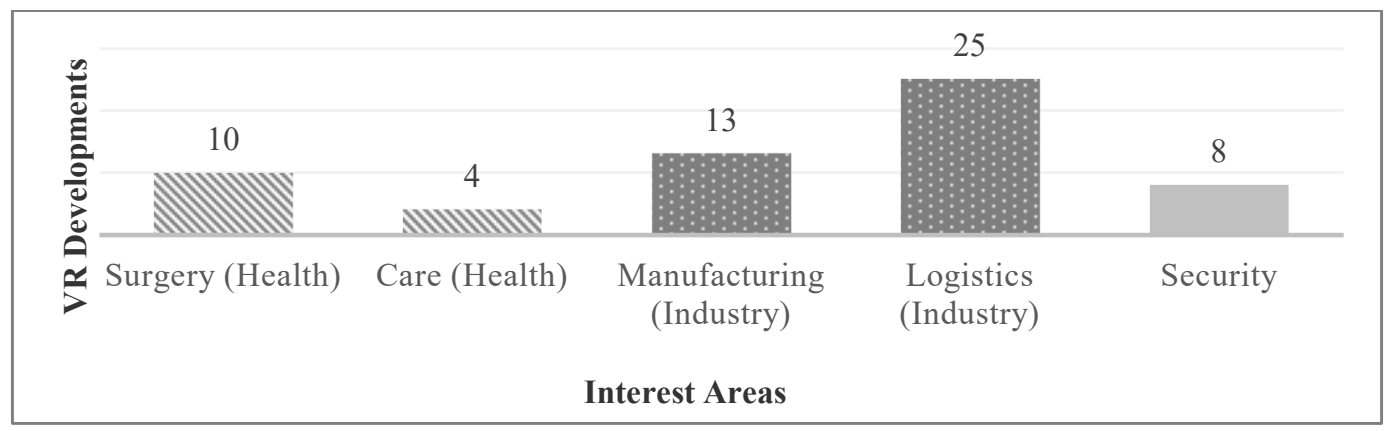

Figure 3. Number of VR developments found in job training by areas of interest. (Own elaboration)

Due to the intrinsically immersive nature of VR applications, simulators were predominant in the developments found. The simulators in real-time pose situations to which the user must react in an immediate time window, generating an interaction that the system takes for instant feedback. In the area of Surgery, applications were developed that do not use the traditional controls of a VR system. These specialties require custom controls or specialized peripherals, to support simulation and provide a more realistic experience [40], [41]. In Logistics [42], an exoskeleton was integrated into the virtual reality system to increase safety and performance in manufacturing lines.

In addition to simulators, there also applications where planning is as predominant as game mechanics [37]. Planning an aneurysm surgery [43], maintaining equipment in a factory [44] or even handling radioactive waste [45] provides greater interaction in the system and more control over the subsequent simulation. 


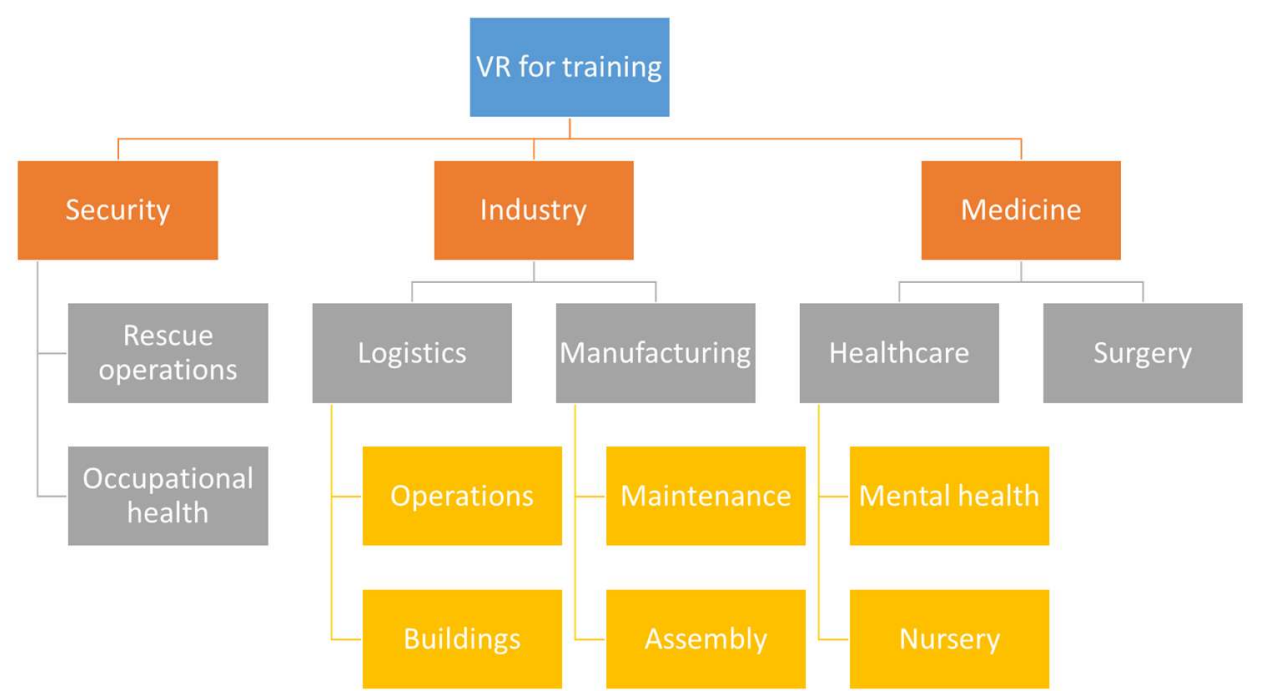

Figure 4. A taxonomy for VR developments found in job training and their areas of interest. (Own elaboration)

\section{CONCLUSIONS}

The use of serious video games and VR in job training allows the appropriation of knowledge, facilitating the acquisition and development of skills, abilities and reacting capabilities in a simulated environment. The use of these tools for job training promotes meaningful learning by actively fostering knowledge by creating a scenario in which those involved can feel in a real work environment, allowing trial-error to achieve the expected learning objectives. Participants in the labor training process can analyze the consequences of the actions carried out, evaluate their learning process, and develop skills and competences.

The documents reviewed show that the use of VR in job-training processes allows companies to reduce costs and optimize times. The savings in training materials focused on new employees contribute to these factors. In addition, employing VR avoids the allocation of production-needed equipment in training tasks, further decreasing the costs of the training process.

Simulation-based systems are predominant in the applications found and planning is as predominant as game mechanics, because the emulation of situations without putting people or machines at risk allows the user to learn in a quiet environment, without the stress, dangers, and responsibilities related to the real activity. Systems with a planning stage are more complex to develop and therefore less common. In both cases, iterative learning is one of the most valuable tools provided by these systems.

\section{ACKNOWLEDGEMENTS}

The authors acknowledge the financial support of the project to the Research, Technological Development and Innovation System of SENA (Sennova) through CESGE.

\section{REFERENCES}

[1] F. J. Pérez Martínez, "Presente y futuro de la tecnología de la realidad virtual," Creat. Soc., vol. XVI, pp. 1-39, 2011.

[2] G. Vera Ocete, J. A. Ortega Carrillo, and M. Á. Burgos González, "La realidad virtual y sus posibilidades didácticas," Etic Net, no. 2, p. 12, 2003.

[3] O. Allal Chérif and M. Bidan, "Collaborative open training with serious games: Relations, culture, knowledge, innovation, and desire," J. Innov. Knowl., vol. 2, no. 1, pp. 31-38, 2017.

[4] M. C. DOrnellas, D. J. Cargnin, and A. L. C. Prado, "Thoroughly Approach to Upper Limb Rehabilitation Using Serious Games for Intensive Group Physical Therapy or Individual Biofeedback Training," in 2014 Brazilian Symposium on Computer Games and Digital Entertainment, 2014, pp. 140-147.

[5] J. Leder, T. Horlitz, P. Puschmann, V. Wittstock, and A. Schütz, "Comparing immersive virtual reality and powerpoint as methods for delivering safety training: Impacts on risk perception, learning, and decision making," Saf. Sci., vol. 111, pp. 271-286, Jan. 2019.

[6] J. C. Morales Saldarriaga, K. Fernández Morales, and J. E. Pulido, "Evaluación de técnicas de producción accesible en cursos masivos, abiertos y en línea - MOOC," Rev. CINTEX, vol. 21, no. 1, pp. 89-112, 2016. 
[7] J. J. Castro-Maldonado, J. A. Patiño-Murillo, A. E. Florian-Villa, and O. E. Guadrón-Guerrero, "Application of computer vision and low-cost artificial intelligence for the identification of phytopathogenic factors in the agroindustry sector," J. Phys. Conf. Ser., vol. 1126, p. 012022, Nov. 2018.

[8] H. D. Ortiz Alzate, L. G. Muñoz Marín, J. Cardeño Espinosa, and N. C. Alzate Osorno, "Impacto del uso de objetos interactivos de aprendizaje en la apropiación de conocimiento y su contribución en el desarrollo de competencias matemáticas: un resultado de experiencia de investigación," Rev. CINTEX, vol. 21, no. 1, pp. $71-$ 88, jun. 2016.

[9] C. Hernandez, D. Velez, and J. A. Isaza, "Diseño de una plataforma de prueba de sensores virtuales para el sistema glucosa-insulina de pacientes UCI usando la técnica HIL," Rev. CINTEX, vol. 23, no. 2, pp. 61-75, Dec. 2018.

[10] A. Peralta and F. P. Romero, "Toma de Decisiones a partir de Conocimiento Extraído tras el Análisis de Comportamientos Previos. Aplicación Práctica para la Dirección de Proyectos de Desarrollo de Software," Rev. CINTEX, vol. 20, no. 2, pp. 97-111, 2015.

[11] J. J. Castro Maldonado, J. A. Patiño Murillo, and C. Gómez López, "Procesos de I+D+i en el Centro de Servicios y Gestión Empresarial del Servicio Nacional de Aprendizaje SENA 2015-2017," Rev. Espac., vol. 39, no. 20, p. 21, 2018.

[12] E. Zapa Pérez, "Impacto de la Gestión por Procesos en la Innovación de las Organizaciones," Rev. CINTEX, vol. 19, pp. 23-37, 2014.

[13] B. Kitchenham, "Procedures for Performing Systematic Literature Reviews," 2004.

[14] Oculus VR, "Walmart Expands VR Training with Oculus Go | Oculus," 2018.

[15] J. Brustein, "Microsoft gana un contrato de \$ 480 millones para el campo de batalla del ejército Bloomberg," 2018.

[16] J. A. Nayhua Gamarra and R. A. Guzmán Neyra, "Uso de Realidad Virtual Inmersiva (RVI) para el entrenamiento de personal en Seguridad, mantenimiento y operaciones." pp. 1-18, 2018.

[17] E. G. G. Verdaasdonk, L. P. S. Stassen, M. P. Schijven, and J. Dankelman, "Construct validity and assessment of the learning curve for the SIMENDO endoscopic simulator," Surg. Endosc., vol. 21, no. 8, pp. 14061412, Jul. 2007.

[18] A. Maciel, L. Youquan, W. Ahn, and P. Singh, "Towards a virtual basic laparoscopic skill trainer. | Center for Modeling, Simulation, \&amp; Imaging in Medicine (VBLaST," Stud. Health Technol. Inform., vol. 132, pp. 27580, 2008.

[19] L. Zhang et al., "The added value of virtual reality technology and force feedback for surgical training simulators.," Work Read. Mass, vol. 41 Suppl 1, pp. 2288-92, 2012.

[20] P. Lamata et al., "SINERGIA laparoscopic virtual reality simulator: Didactic design and technical development," Comput. Methods Programs Biomed., vol. 85, no. 3, pp. 273-283, Mar. 2007.

[21] Consorcio OPENSURG, Robótica médica: Notas prácticas para el aprendizaje de robótica en bioingeniería, consorcio OPENSURG. 2012.

[22] A. Nasr, J. T. Gerstle, B. Carrillo, and G. Azzie, "The Pediatric Laparoscopic Surgery (PLS) simulator: Methodology and results of further validation," J. Pediatr. Surg., vol. 48, no. 10, pp. 2075-2077, Oct. 2013.

[23] E. Salas and M. E. Gregory, "A Medical VR Simulator in Laparoscopic Rectum Surgery," 2014.

[24] L. A. Ospina Ospina and J. F. Escobar Soto, "La simulación como estrategia pedagógica y didáctica en la formación integral en el SENA," in III Simposio Nacional de Formación con Calidad y Pertinencia, 2016.

[25] C. M. López Gutiérrez and J. P. Arias Herrera, Oscar Arnmando Giraldo Escobar, "Entrenamiento Interactivo (3D) en Redes de Distribución de Energía Eléctrica | Megavatios," Megavatios, 2018.

[26] D. Grajewski et al., "Improving the Skills and Knowledge of Future Designers in the Field of Ecodesign Using Virtual Reality Technologies," in Procedia Computer Science, 2015, vol. 75, pp. 348-358.

[27] G. Sankaranarayanan et al., "Validation of a novel laparoscopic adjustable gastric band simulator," Surg. Endosc., vol. 25, no. 4, pp. 1012-1018, Apr. 2011.

[28] D. W. Carruth, "Virtual reality for education and workforce training," in ICETA 2017 - 15th IEEE International Conference on Emerging eLearning Technologies and Applications, Proceedings, 2017.

[29] L. Chittaro, C. L. Corbett, G. A. McLean, and N. Zangrando, "Safety knowledge transfer through mobile virtual reality: A study of aviation life preserver donning," Saf. Sci., vol. 102, pp. 159-168, Feb. 2018.

[30] S. Londoño Marín, J. A. Londoño Gallego, J. J. Castro Maldonado, and J. A. Patiño Murillo, "Guía interactiva para el desarrollo de proyectos bajo la Metodología de Marco Lógico," Rev. Espac., vol. 39, no. 47, p. 25, 2018.

[31] Y. Shi, J. Du, C. R. Ahn, and E. Ragan, "Impact assessment of reinforced learning methods on construction workers' fall risk behavior using virtual reality," Autom. Constr., vol. 104, pp. 197-214, Aug. 2019.

[32] T. Haase and W. Termath, "A Virtual Interactive Training Application for Supporting Service Technicians in the Field of High Voltage Equipment," in Procedia Computer Science, 2015, vol. 77, pp. 207-214.

[33] B. Z. Roitberg, P. Kania, C. Luciano, N. Dharmavaram, and P. Banerjee, "Evaluation of Sensory and Motor 
Skills in Neurosurgery Applicants Using a Virtual Reality Neurosurgical Simulator: The Sensory-Motor Quotient," J. Surg. Educ., vol. 72, no. 6, pp. 1165-1171, 2015.

[34] S. Kavanagh, A. Luxton-Reilly, B. Wuensche, and B. Plimmer, "A Systematic Review of Virtual Reality in Education.," Themes Sci. Technol. Educ., vol. 10, no. 2, pp. 85-119, 2017.

[35] B. A. J. Menelas, C. Haidon, A. Ecrepont, and B. Girard, "Use of virtual reality technologies as an ActionCue Exposure Therapy for truck drivers suffering from Post-Traumatic Stress Disorder," Entertain. Comput., vol. 24, pp. 1-9, Jan. 2018.

[36] J. J. Roldán, E. Crespo, A. Martín-Barrio, E. Peña-Tapia, and A. Barrientos, "A training system for Industry 4.0 operators in complex assemblies based on virtual reality and process mining," Robot. Comput. -Integr. Manuf., vol. 59, pp. 305-316, Oct. 2019.

[37] P. A. Winkes and J. C. Aurich, "Method for an enhanced assembly planning process with systematic virtual reality inclusion," in Procedia CIRP, 2015, vol. 37, pp. 152-157.

[38] M. A. Rizzuto, M. W. L. Sonne, N. Vignais, and P. J. Keir, "Evaluation of a virtual reality head mounted display as a tool for posture assessment in digital human modelling software," Appl. Ergon., vol. 79, pp. 1-8, Sep. 2019.

[39] S. Tretsiakova-McNally, E. Maranne, F. Verbecke, and V. Molkov, "Mixed e-learning and virtual reality pedagogical approach for innovative hydrogen safety training of first responders," Int. J. Hydrog. Energy, vol. 42, no. 11, pp. 7504-7512, Mar. 2017.

[40] J. Cecil, A. Gupta, M. Pirela-Cruz, and P. Ramanathan, "An loMT based cyber training framework for orthopedic surgery using Next Generation Internet technologies," Inform. Med. Unlocked, vol. 12, pp. 128-137, Jan. 2018.

[41] A. Bernardo, "Virtual Reality and Simulation in Neurosurgical Training," World Neurosurg., vol. 106, pp. 1015-1029, Oct. 2017.

[42] A. Karvouniari, G. Michalos, N. Dimitropoulos, and S. Makris, "An approach for exoskeleton integration in manufacturing lines using Virtual Reality techniques," in Procedia CIRP, 2018, vol. 78, pp. 103-108.

[43] R. A. Kockro et al., "Aneurysm Surgery with Preoperative Three-Dimensional Planning in a Virtual Reality Environment: Technique and Outcome Analysis," World Neurosurg., vol. 96, pp. 489-499, Dec. 2016.

[44] A. Fast-Berglund, L. Gong, and D. Li, "Testing and validating Extended Reality (xR) technologies in manufacturing," in Procedia Manufacturing, 2018, vol. 25, pp. 31-38.

[45] V. G. G. Freitas, A. Carlos De Abreu Mol, and R. Shirru, "Virtual reality for operational procedures in radioactive waste deposits," Prog. Nucl. Energy, vol. 71, pp. 225-231, Mar. 2014. 